\title{
Aplikasi Pemantauan Posisi Anak-Anak Menggunakan Smart Watch dan Database Firebase
}

\author{
${ }^{1}$ I N E Indrayana, ${ }^{2}$ Putu Sutawinaya, ${ }^{3}$ Kadek Amerta Yasa , ${ }^{4} \mathrm{~N}$ M Wirasyanti D P \\ 1,2,3 Jurusan Teknik Elektro \\ ${ }^{4}$ Jurusan Akuntansi \\ Politeknik Negeri Bali \\ eddyindrayana@pnb.ac.id
}

\begin{abstract}
Abstrak
Keamanan anak - anak menjadi perhatian para orang tua di jaman modern ini. Kriminalitas terhadap anak- anak sering mengancam mereka, disaat pengawasan orang tua lemah. Orang tua tidak dapat memantau setiap saat aktivitas anak-anak mereka. Kesibukan orang tua untuk mendapatkan uang menyebabkan mereka terbatas dalam memantau kegiatan anak-anak, terutama anak-anak mereka yang masih duduk di taman kanak-kanak dan sekolah dasar. Orang tua memerlukan suatu alat ataupun aplikasi yang dapat membantu pemantauan posisi anak-anak pada setiap saat. Untuk itu dibangun suatu aplikasi pemantauan posisi anak anak dengan menggunakan smart watch dan database realtime Firebase. Pembuatan perangkat lunak pada penelitian ini menggunakan metode Unified Software Development Process (USDP) yang memiliki 4 fase kerja yaitu Inception, Elaboration, Construction dan Transition. Perangkat lunak ini melibatkan 2 aktor yaitu aktor "anak" dan aktor "orang tua". Aktor "anak" akan mengirimkan posisi latitude dan longitude melalui smart watch yang dipakainya. Aktor "orang tua" akan melihat posisi anak dalam map pada layar smart phone secara realtime.
\end{abstract}

Keywords: Firebase,Smartwatch, Aplikasi Pemantauan Anak Anak.

\begin{abstract}
Child safety is a concern for parents in this modern era. Crime against children often threatens them, when parental supervision is weak. Parents cannot monitor at all times the activities of their children. Parents have little time to monitor their children's activities because they are busy with their work, especially their children who are still sitting in kindergartens and elementary schools. Parents need a tool or application that can help monitor the position of children at all times. For this purpose, an application for monitoring the position of children was built using the Smart watch and Firebase realtime database. The making of software in this study uses the Unified Software Development Process (USDP) method which has 4 phases of work namely Inception, Elaboration, Construction and Transition. This software involves 2 actors namely "child" actor and "parent" actor. The "child" actor will send latitude and longitude positions through the smart watch he uses. Actors "parents" will see the child's position in a map on the mobile screen in realtime.
\end{abstract}

Keywords: Firebase, Smart watch, Children Monitoring Application.

\section{Pendahuluan}

Angka kriminalitas terhadap anak-anak tiap tahunnya terus meningkat. pada tahun 2014, data kasus penculikan anak yang masuk ke Komnas Anak sebanyak 51 Kasus. Kemudian tahun 2015 , kasus penculikan anak yang masuk ke Komnas Anak sebanyak 87 kasus. Untuk tahun 2016, jumlah kasus penculikan anak menjadi 112 kasus.Kalau dilihat dari data ini terdapat peningkatan jumlah kasus dari tahun ke tahun[1]. Kriminalitas dapat terjadi kapan saja dan pelakunya sering kali orang dekat di anak itu sendiri. Orang tua tidak dapat menemani setiap 
saat anaknya. Kesibukan orang tua mencari nafkah menyebabkan mereka terbatas dalam memantau aktivitas anak terutama anak-anak mereka yang masih duduk di sekolah taman kanak-kanak(TK) dan sekolah dasar(SD). Apalagi tuntutan biaya hidup jaman sekarang ini menuntut orang tua untuk bekerja keras untuk memenuhi kebutuhan keluarganya. Hal ini menyebabkan dilema bagi orang tua, apakah harus mengutamakan mencari nafkah ataukah menemani aktifitas si anak. Tentunya kondisi idealnya adalah dapat seimbang pembagian waktu antara mencari nafkah dan memantau keberadaan anak-anak mereka. Pada saat orang tua melakukan aktifitas mencari nafkah, mereka juga ingin mengetahui dimana saja posisi anak mereka.

Kemajuan teknologi dalam penggunaan global positioning system(GPS) sangat banyak digunakan dewasa ini untuk mengetahui posisi dari suatu objek di bumi[2]. GPS juga dapat digunakan untuk melakukan penelusuran jejak (tracking) objek[3]. Salah satu pemanfaatan GPS adalah untuk mengetahui posisi dari anak-anak dalam melakukan aktifitasnya sehari hari. Teknologi GPS juga dapat melakukan tracking lokasi mana saja yang sering dikunjungi oleh si anak[4]. Kordinat GPS diperoleh dari satelit berupa data latitude dan longitude lokasi suatu objek.

Ada beberapa penelitian sebelumnya yang berhubungan dengan penelitian ini, diantaranya penelitian Roly Segara dan Subari, menggunakan teknologi GPS untuk memantau lokasi anak menggunakan metode geofence pada platform android. Penelitiannya dilengkapi dengan teknik geofencing[8]. Geofencing merupakan sebuah perimeter virtual pada wilayah geografis yang menggunakan layanan berbasis lokasi digunakan untuk pembatasan wilayah pengawasan anak. Apabila anak berpindah posisi melewati batas geofencing yang ditetapkan akan muncul notifikasi kepada orang tua berupa pesan atau alarm melalui perangkat smart phone. Penelitian Anyar Muawal dan Baizul Zaman mengimplementasikan teknologi gps tracking smart phone sebagai aplikasi monitoring lokasi anak[4]. Aplikasi ini bertujuan untuk membantu dalam mengawasi anak dalam kegiatan sehari - harinya khususnya lokasi yang sering di datanginya. Dalam penelitian Anyar Muawal ini, google map digunakan sebagai media untuk menampilkan posisi dari si anak secara realtime. Kedua belah pihak baik sisi anak maupun orang tua samasama menggunakan perangkat smart phone android dalam menjalankan aplikasinya. Anusha $\mathrm{R}$ dan Naidu C. A melakukan penelitian menggunakan GPS, RFID, GSM dan ARM processor untuk membantu penelusuran jejak(tracking) dari siswa dalam suatu sekolah. Penelitian Anusha ini bertujuan untuk mengetahui siswa yang tidak berada di lokasi sekolah pada jam pelajaran[9]. Steven van der spek melakukan penelitian dengan teknologi GPS. Dalam penelitiannya, steven mengungkapkan bahwa teknologi GPS memungkinkan penggunaan perangkat GPS tidak hanya sebagai alat navigasi dan orientasi, tetapi juga sebagai instrumen yang digunakan untuk menangkap rute perjalanan dimana sebagai sensor untuk mengukur aktivitas pada skala kota atau skala regional. Penelitian ini dikembangkan di TU Delft, dimana proses dan arsitektur database digunakan untuk mengumpulkan data pergerakan pejalan kaki di tiga pusat kota Eropa, Norwich, Rouen dan Koblenz[10]. Trupti R.C melakukan penelitian berfokus pada pelacakan posisi dan lokasi anak yang dikirim ke ruang kontrol sekolah dan ponsel orang tua. Penelitian Trupti juga bertujuan untuk mengetahui apakah anak hadir atau tidak di sekolah dan memberikan sinyal yang sama kepada sekolah dan orang tua. Tangisan anak juga direkam sebagai identifikasi si anak. Ketika cocok dengan tangisan anak di sekolah, pesan teks berisi lokasi seorang anak akan dikirim ke orang tua. Dengan menggunakan nilai garis bujur dan garis lintang, lokasi seorang anak dapat dilacak dengan menggunakan aplikasi di ponsel orang tua[11].

Sedangkan pada penelitian ini dibangun suatu aplikasi menggunakan data koordinat latitude dan longitude posisi anak yang ditangkap oleh alat GPS. Data ini akan dikirim ke server yang selanjutnya lokasi keberadaan anak ini ditampilkan pada perangkat smart phone milik orang tua. Anak - anak diberikan perlengkapan yang ringan sehingga mudah dibawa dalam melakukan aktifitasnya. Alat ini akan mengirimkan data lokasi secara simultan ke server pada saat anak tidak melakukan aktifitas maupun pada saat anak-anak berpindah posisi. Pada Aplikasi ini digunakan Firebase Realtime Database sebagai media penyimpan data. Firebase adalah database yang menyimpan data di server cloud. Firebase dapat berjalan dengan baik di beberapa platform seperti Apple iOS, Android dan Web [12] [13]. Firebase akan menyimpan datanya dalam struktur JSON (Java Script Object Notation)[14][15]. Sinkronisasi secara otomatis akan dilakukan oleh firebase, pada saat aplikasi terhubung ke server. Kemudian server akan melakukan update data terbaru ke sisi client. Dalam membangun struktur 
database firebase pengembang aplikasi harus memperhatikan hal - hal berikut ini, yaitu berusaha membuat struktur data pohon JSON yang rata, sehingga data yang bertingkat dapat dihindari[16][17]. Firebase juga mengoptimalkan waktu pada saat akses data[18]. Firebase menyediakan serangkaian fitur yang lengkap untuk mengelola keamanan aplikasi. Fitur ini memudahkan programmer dalam mengautentifikasi pengguna, mengelola hak akses pengguna, dan melakukan validasi input data. Aplikasi yang didukung Firebase menjalankan lebih banyak kode sisi client. Langkah pertama yang umum dalam mengamankan aplikasi Anda adalah mengidentifikasi pengguna aplikasi. Kita dapat menggunakan Firebase Authentication sebagai sarana pengguna untuk melakukan login ke aplikasi. Database realtime firebase merupakan salah satu database yang memiliki performa yang tinggi dalam mengolah data yang besar[19].

\section{Methodologi}

Penelitian ini menggunakan metode pengembangan rekayasa perangkat lunak Unified Software Development Process(USDP). USDP merupakan metodologi untuk pengembangan perangkat lunak, terutama perangkat lunak yang berorientasikan objek. Metode ini diawali dengan pembuatan Use case yang pada prinsipnya untuk mendapatkan spesifikasi kebutuhan pengguna. Metode USDP memiliki 4 fase kerja yaitu Inception, Elaboration, Construction dan Transition[20]. Pada masing-masing fase terdapat tahapan yang dilakukan iterasi yaitu tahap requirements, analisis, perancangan, implementasi dan pengujian.

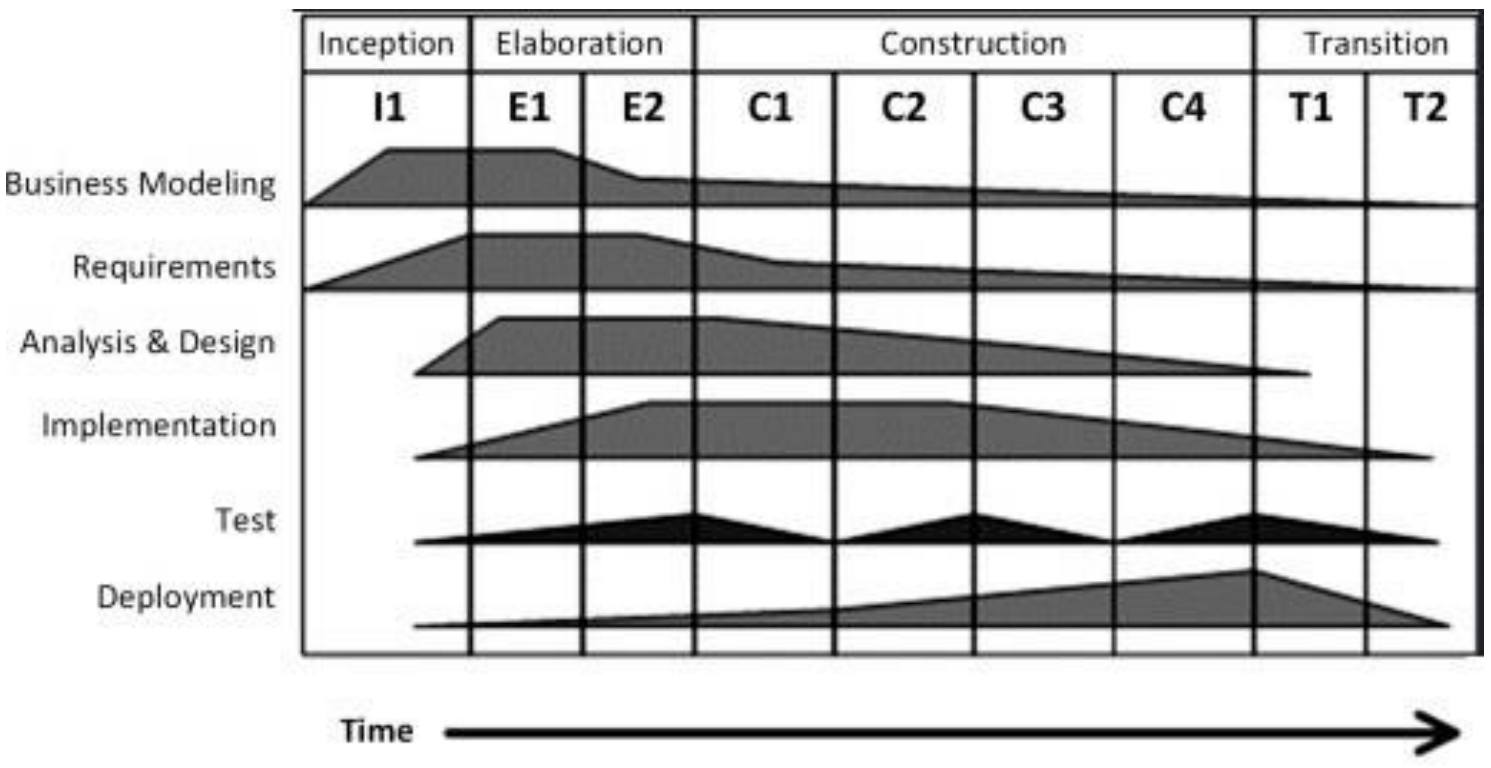

Gambar 1. Metode Unified Software Development Process[21]

Fase Inception merupakan fase pengembang perangkat lunak melakukan interaksi dengan pengguna aplikasi. Fase ini ditujukan sebagai langkah awal untuk pengidentifikasian kebutuhan-kebutuhan aplikasi yang akan dibangun. Pada tahapn ini diharapkan ada persamaan persepsi antara para pengembang perangkat lunak dengan si pengguna aplikasi. Persamaan persepsi meliputi data awal sebagai input sistem dan output yang diiginkan dari pengguna aplikasi.

Fase Elaboration Fase ini digunakan untuk menyempurnakan konsep-konsep yang sudah terbentuk di fase Inception. Fase ini digunakan untuk merancang sistem. Untuk pendekatan sistem berbasis objeck dapat menggunakan Unified Modeling Language (UML). Pada tahapan ini belum ada kegiatan coding. Masih kegiatan penyempurnaan dan peninjauan kembali terhadap rancangan. Menganalisa kemungkinan kemungkinan yang diperlukan dalam setiap rancangan proses sehingga resiko kesalahan pembuatan sistem dapat dihindari.

Fase Construction. Fase ini merupakan fase coding. Programmer perangkat lunak menerjemahkan rancangan sistem yang sudah dibuat pada fase elaboration, kedalam coding bahasa pemrograman. User interface(UI) diimplementasikan sesuai rancangan yang telah 
dibuat. Proses - proses diimplementasikan dengan menggunakan parameter parameter yang sudah ditentukan pada tahap sebelunya.

Fase Transition. Tahap ini dilakukan untuk menyempurnakan produk akhir yang sudah jadi. Pada tahapan ini dilakukan testing perangkat lunak kepada pihak pengguna. Kode - kode program yang masih salah, dilakukan perbaikan untuk disempurnakan. Penyempurnaan ini perlu dilakukan untuk menganalisa apakah perangkat lunak yang sudah dibuat sesuai dengan kebutuhan pengguna. Mempersiapkan segala kebutuhan supaya perangkat lunak siap dipergunakan oleh pengguna, termasuk malakukan seting hardware dan konfigurasi di sisi pengguna.Mempersiapkan manual book dan pelatihan kepada pengguna mengenai cara mengoperasikan perangkat lunak yang dibangun.

\section{Hasil Dan Pembahasan}

\subsection{Fase Inception}

Langkah yang dilakukan pada tahap ini adalah yaitu melakukan pengumpulan data input yang dibutuhkan dan output yang ingin disajikan untuk pengguna. Data yang dibutuhkan dalam membangun aplikasi pemantauan posisi anak dengan smart watch ini, diantaranya nama keluarga, orang tua, anak, dan posisi latitude dan longitude dari si anak. Family memiliki atribut id keluarga yang dapat berupa email dari orang tua ,nama keluarga. Orang tua memiliki atribut id orang tua dapat berupa no smart phone, nama orang tua, dan kata sandi. Dari sisi Anak, ada beberapa data yang diperlukan dalam aplikasi ini. data tersebut adalah id anak dapat digunakan nomor smart phone yang digunakan oleh anak. Nomor kartu sim smart phone si anak akan dipasang di alat smart watch. Selain itu dibutuhkan nama anak, kata sandi dan posisi latitude longitude dari si anak.

Infiormasi yang disajikan oleh aplikasi ini, diantaranya:

- Menampilkan daftar anak anak dari satu keluarga

- Menampilkan semua posisi anak pada google map

Perangkat yang dibutuhkan

- Smart watch yang dilengkapi dengan GPS

- Smart phone dengan sistem operasi Android

- Database Realtime Firebase sebagai penyimpan data.

\section{Arsitektur Sistem}
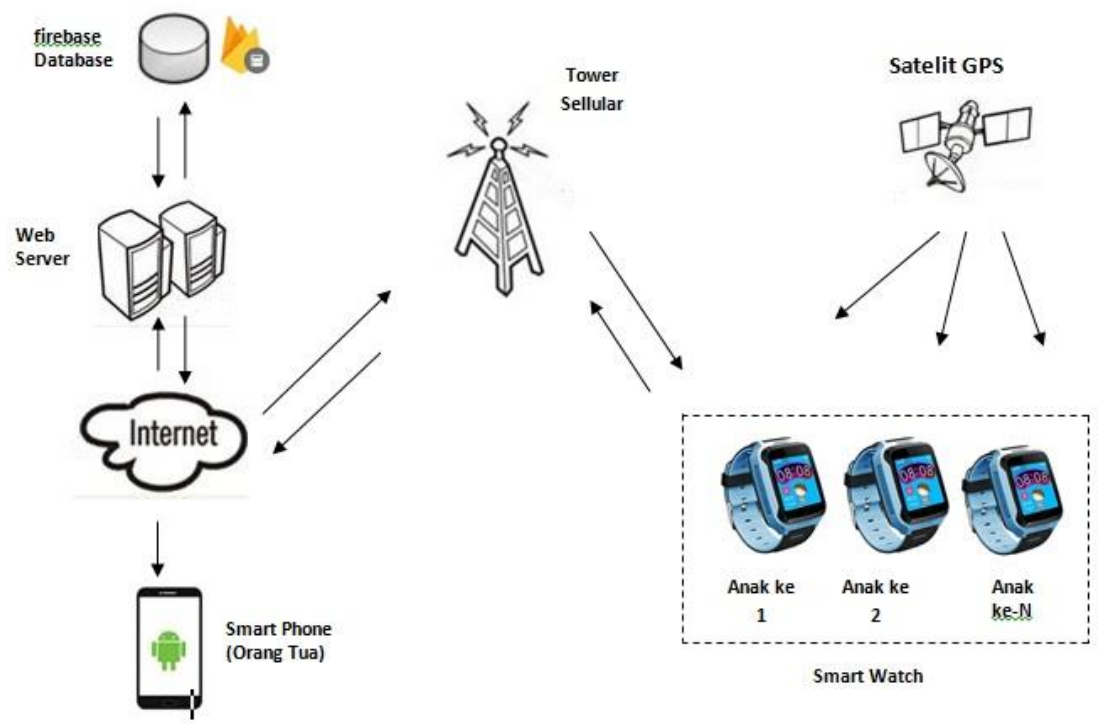

Gambar 1. Arsitektur Perangkat Lunak Pemantauan Posisi Anak 
Gambar 1, menunjukkan perangkat smartwatch digunakan oleh pengguna "anak", dimana dilengkapi dengan perangkat GPS. Koordinat latitude dan longitude diperoleh dari satelite GPS. Koordinat dari si pemakai smart watch akan dikirimkan melalui jaringan internet.Koordinat ini akan disimpan menggunakan database firebase yang berada di server cloud. Smart phone akan melakukan permintaan data koordinat latitude dan longitude posisi anak. Kemudian posisi anak ini akan ditampilkan dalam google map dilayar smart phone orang tua.

\subsection{Fase Elaborasi}

Pada tahap ini dilakukan perancangan struktur Database Firebase untuk aplikasi pemantauan posisi anak. Rancangan Struktur Firebase dapat dilihat pada gambar 2. Salah satu pertimbangan dalam membuat struktur realtime database firebase adalah pembuat aplikasi haus menyesuaikan dengan informasi yang akan ditampilkan pada aplikasi. Pada aplikasi ini penyajian informasi pada layar smartphone tidak terlalu rumit, yaitu menampilkan ke layar smart phone nama semua anak dalam satu keluarga. Informasi yang lain adalah menampilkan posisi anak pada map.

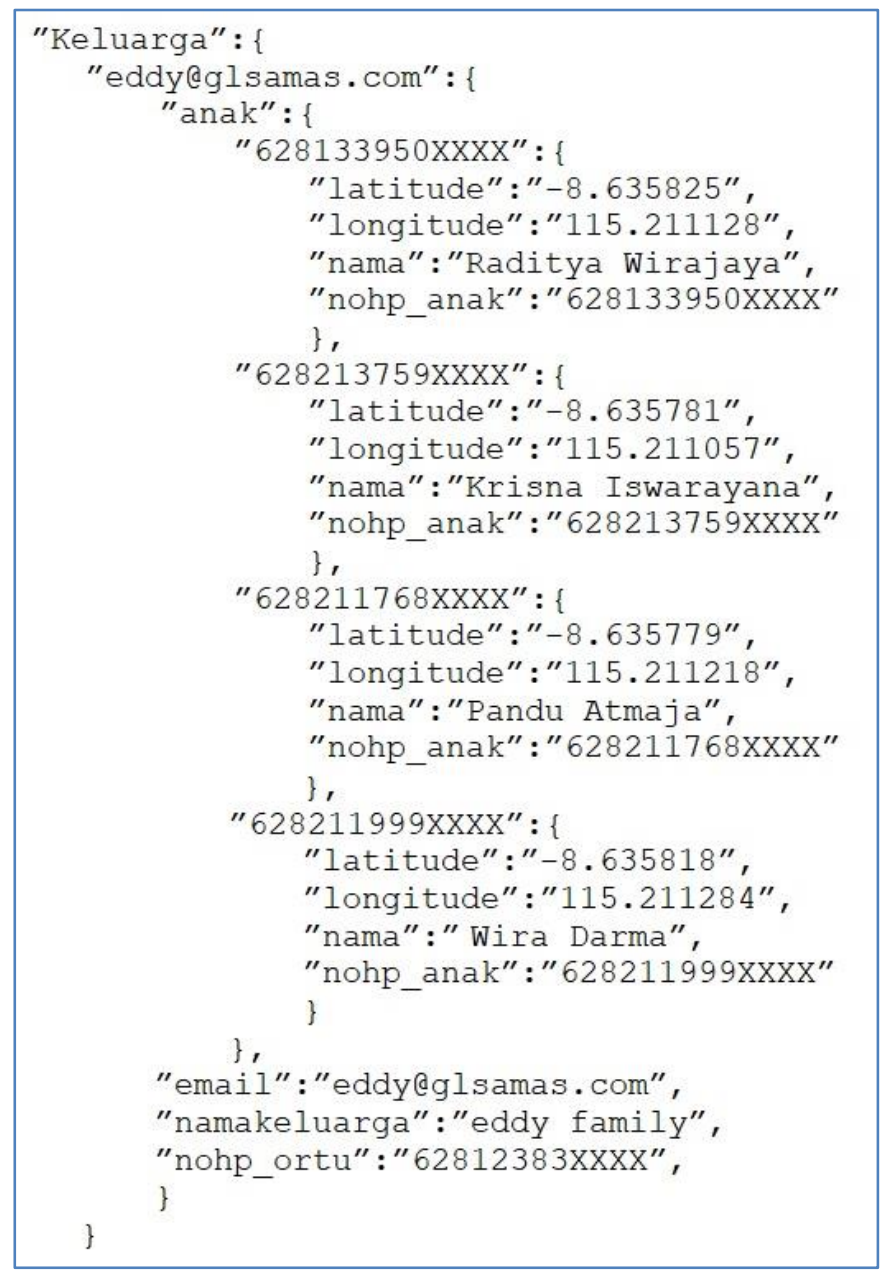

Gambar 2. Rancangan Struktur Firebase Aplikasi Pemantauan Posisi Anak

Pada fase elaborasi ini juga dilakukan perancangan perangkat lunak menggunakan UML. Pada tahapan ini dilakukan perancangan use case diagram, activity diagram. Gambar 3 adalah gambar use case sistem. Dalam Use case tersebut terdapat 2 aktor yaitu orang tua dan anak. Orang tua dapat melakukan case "membuat group keluarga", "mendaftarkan anak","menampilkan semua anak dalam satu keluarga", "menampilkan posisi anak pada map". Sedangkan aktor anak dapat melakukan case "mengirimkan posisi" dan "SOS menelepon 
orang tua ". Aktor orang tua terlebih dahulu melakukan case "Login orang tua" sebelum melakukan case yang lain, begitu pula aktor anak melakkan case "Login untuk anak".

Aktor "orang tua" dapat melakukan case "membuat group keluarga". pada case ini orang tua dapat membuat satu nama keluarga dimana sebagai identitas adalah email dari orang tua itu sendiri. Case "mendaftarkan anak" memungkinkan orang tua untuk menambah data anggota keluarganya. Sehingga satu group keluarga dapat memiliki beberapa anak. Case "menampilkan semua anak dalam satu keluarga" adalah fasilitas, dimana orang tua dapat melihat daftar dari semua nama-nama anggota keluarganya. Case"menampilkan posisi anak pada map", memungkinkan orang tua dapat melihat semua posisi anggota keluarganya pada google map.

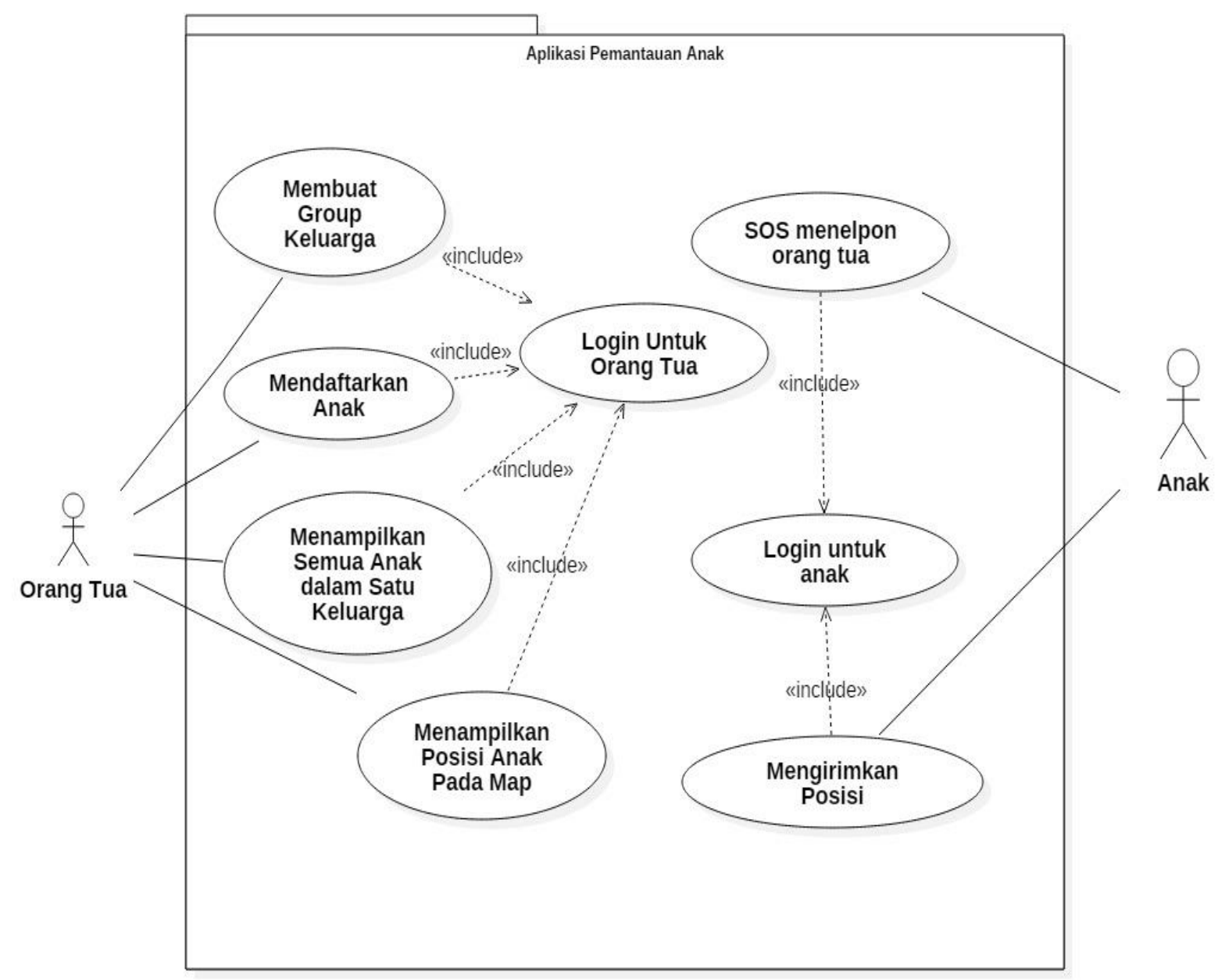

Gambar 3. Gambar Use Case Aplikasi Pemantauan Posisi Anak

Case "mengirim posisi" digunakan untuk melakukan pengiriman data posisi dari aktor anak. Position dari anak diperoleh dengan mengaktifkan alat GPS pada smartwatch dimana akan memperoleh data latitude dan longitude. Smart watch yang digunakan oleh anak akan mengirimkan data ini ke server untuk disimpan pada database firebase.Case "SOS menelepon orang tua" disediakan oleh aktor "anak" untuk melakukan kontak ke nomor smart phone orang tua pada keadaan darurat. 


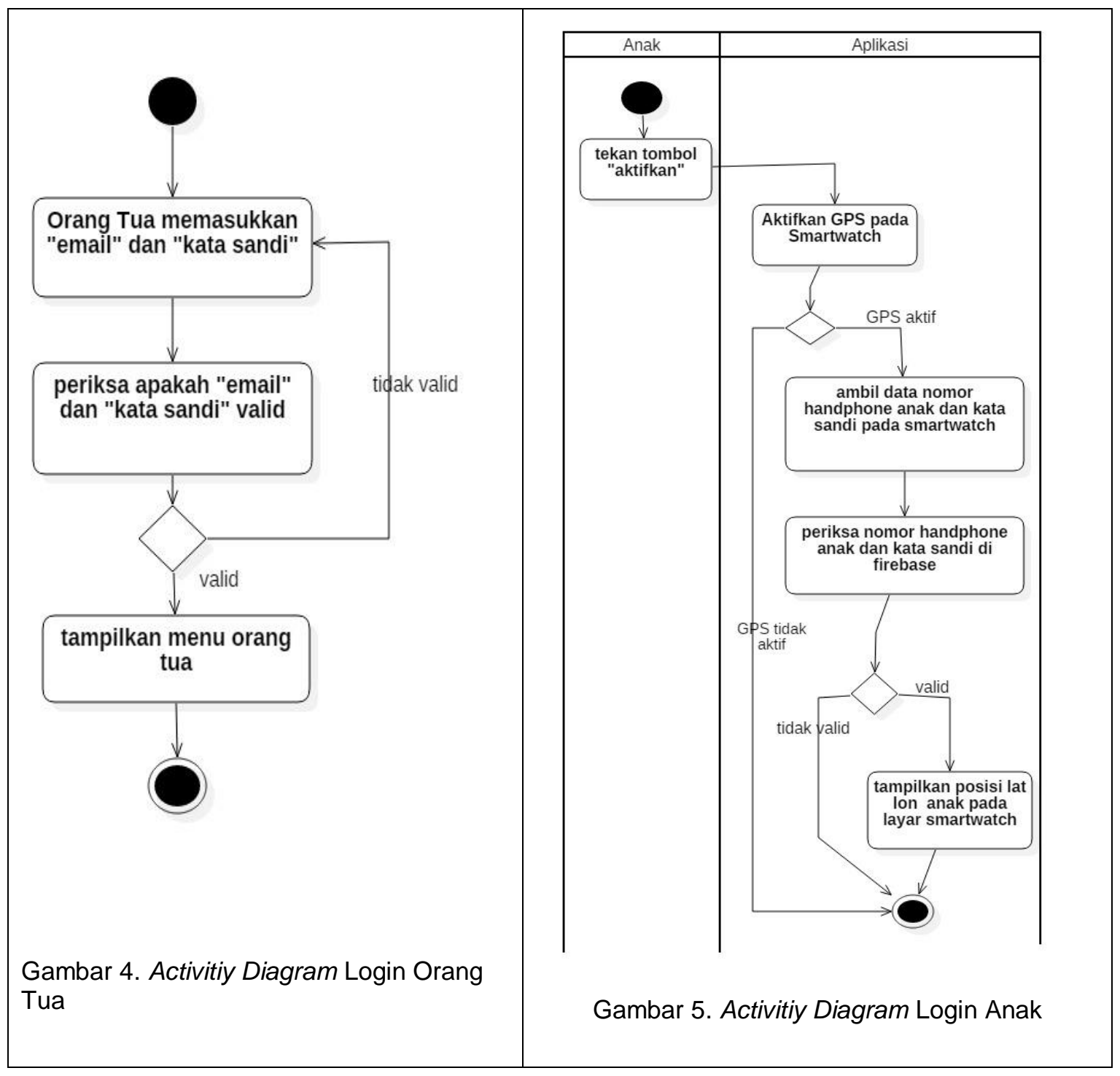

Gambar 4. menunjukkan activity diagram login orang tua. Pengguna sebagai orang tua dapat melakukan login ke aplikasi dengan memasukkan email orang tua dan kata sandi. Jika email dan kata sandi yang masukkan oleh orang tua terdaftar dalam database firebase dan dinyatakan valid oleh sistem, maka pengguna orang tua dapat amasuk ke aplikasi dan aplikasi akan menampilkan menu untuk orang tua. Gambar 5 merupakan activity diagram login anak, dimana kata sandi dan nomor smart phone dari si anak tersimpan di smart watch. Si anak akan mengaktifkan aplikasi untuk memulai mengirimkan koordinat latitude dan longitude posisi dirinya. Sebelum mengaktifkan aplikasi berhasil, terlebih dahulu dilakukan pemeriksaan terhadap kata sandi dan nomor smart watch anak di database firebase. Jika valid maka, si anak dapat mengaktifkan aplikasi pada smart watch. 


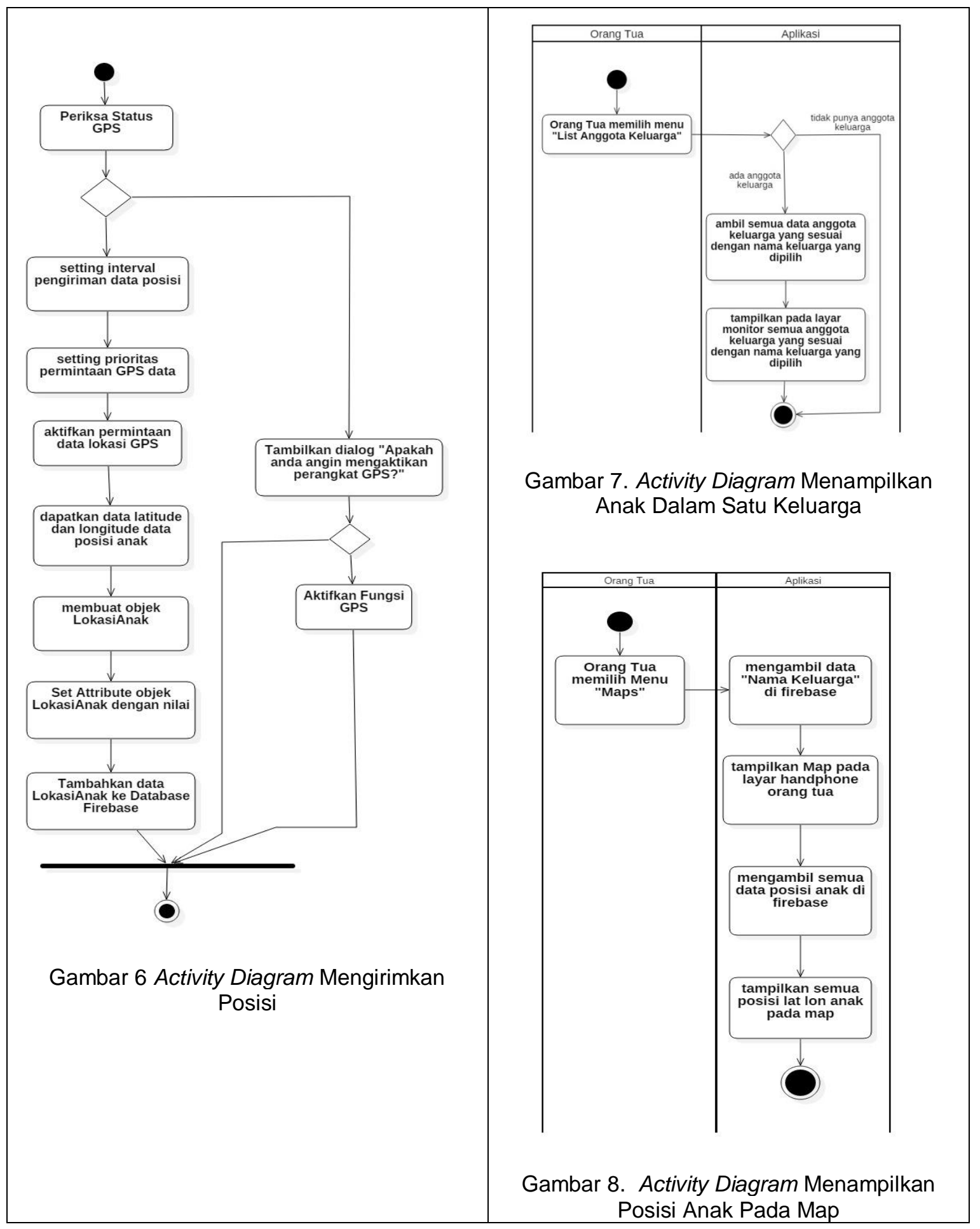

Gambar 6 adalah activity diagram mengirimkan posisi. Activity ini dilakukan oleh anak melalui perangkat smartwatch. Perangkat GPS dari smart watch terlebih dahulu diaktifkan, jika belum aktif tampilkan konfirmasi kepada pengguna anak untuk mengaktifkan perangkat GPS. Jika sudah aktif, smartwatch dapat melakukan pengiriman secara berkala posisi latitude dan longitude dari pengguna anak yang sudah ditentukan interval terlebih dahulu. Posisi latitude dan longitude ini akan dikirimkan ke database firebase. Gambar 7 adalah activity diagram menampilkan anak dalam satu keluarga. Aplikasi akan mencari data anggota keluarga di database firebase sesuai dengan nama keluarga yang dipilih. Kemudian aplikasi akan menampilkan daftar semua nama anak dalam satu keluarga ke layar phone sale orang tua. Gambar 8 adalah activity diagram menampilkan posisi anak pada map. Activity ini terlebih 
dahulu akan menagmbil data nama keluarga yang dipilih dan melakukan pencarian terhadap semua anggota kelurganya. Data latitude dan longitude dari setiap anggota keluraga akan divisualisasikan pada map di layar smart phone orang tua. Posisi masing masing anak akan dilengkapi dengan tag icon position dan nama si anak.

\subsection{Fase Construction}

Fase ini melakukan coding dari perancangan sistem yang sudah dilakukan pada tahap sebelumnya ke bahasa pemrograman Java. Integrated Development Environment(IDE) adalah Android Studio yang merupakan IDE resmi untuk pegembangan aplikasi dengan sistem operasi android. Aplikasi ini menggunakan fasilitas map dari google. Untuk menggunakan Maps JavaScript API, kita harus memiliki API key. API key adalah kunci unik yang digunakan untuk mengautentikasi permintaan yang terkait dengan aplikasi yang kita buat dalam hal penggunaan resource map dari google. Untuk implementasi firebase pada aplikasi, kita harus dipastikan tmenggunakan target API level 16 (Jelly Bean) atau yang lebih baru dan menggunakan Gradle 4.1 atau yang lebih baru. Implementasi pada smart watch menggunakan smart watch Q1 Pro dengan sistem operasi Android 6.0, CPU: MTK6737 Quad Core,1.3GHz

\subsection{Fase Transition}

Fase ini dilakukan pengujian terhadap perangkat lunak yang dibuat. Pengujian perangkat lunak dilakukan disesuaikan dengan kondisi lingkungan sebenarnya. Pengujian perangkat lunak anak menggunakan 4 buah smart watch dari sisi pengguna anak, dan satu smart phone android dari sisi pengguna orang tua. Bebesapa tampilan perangkat lunak sistem dapat dilihat pada gambar berikut.

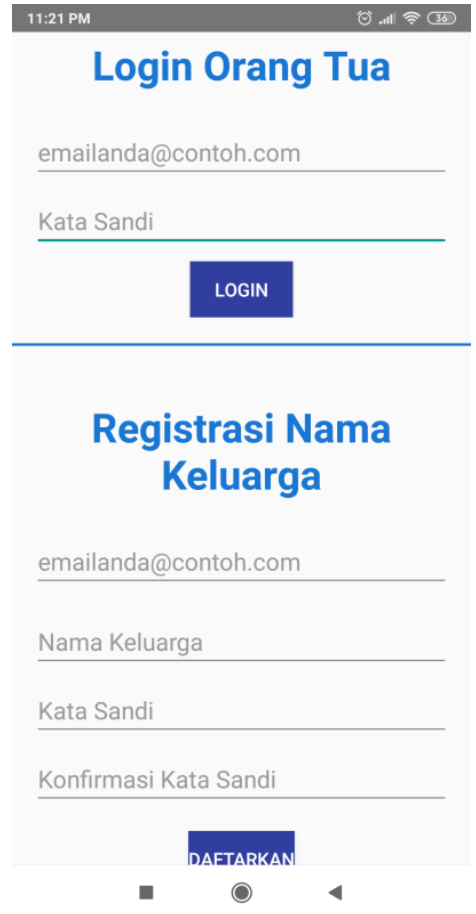

Gambar 9. Tampilan Login Orang Tua dan Registrasi Nama Keluarga

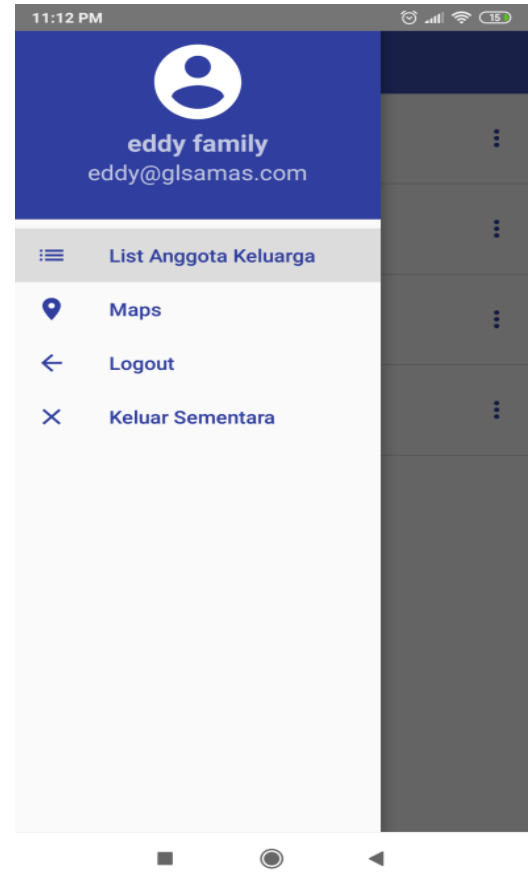

Gambar 10. Tampilan Menu Orang Tua 
Aplikasi Pemantauan Posisi Anak-Anak Menggunakan Smart Watch dan Database Firebase Indrayana, dkk.

\begin{tabular}{ll}
$\begin{array}{l}\text { 11:24 PM } \\
\equiv \quad \text { List Anggota Keluarga }\end{array}$ & \\
\hline $\begin{array}{l}\text { Raditya Wirajaya } \\
081334562456\end{array}$ & $\vdots$ \\
\hline $\begin{array}{l}\text { Krisna Iswarayana } \\
08123832059\end{array}$ & $\vdots$ \\
\hline $\begin{array}{l}\text { Pandu Atmaja } \\
081335622778\end{array}$ & $\vdots$ \\
\hline $\begin{array}{l}\text { Wira Darma } \\
08256166161\end{array}$ & $\vdots$ \\
\hline
\end{tabular}

Gambar 11. Tampilan Daftar Semua Anak Dalam Satu Keluarga

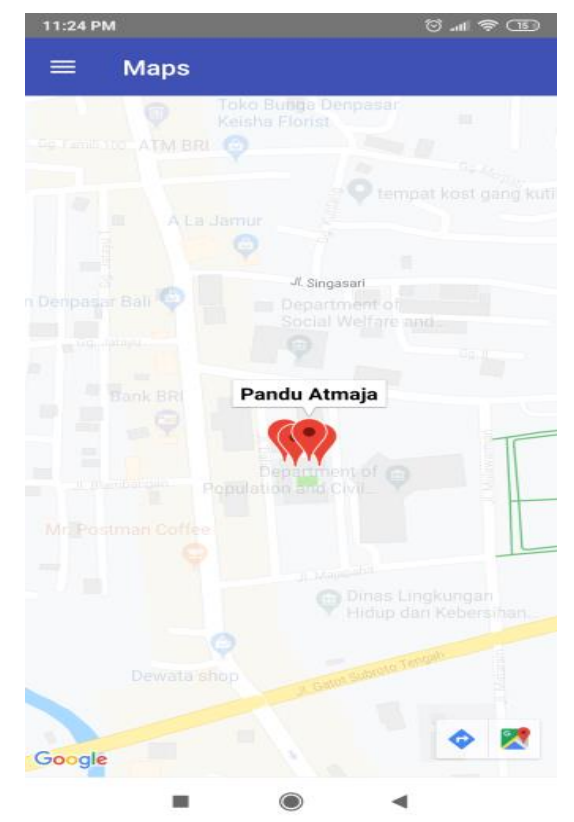

Gambar 13 Tampilan Posisi Semua Anak pada MAps

\begin{tabular}{ll}
\hline $\begin{array}{l}\text { 11:23 PM } \\
\equiv \quad \text { List Anggota Keluarga }\end{array}$ \\
\hline $\begin{array}{l}\text { Raditya Wirajaya } \\
081334562456\end{array}$ \\
\hline $\begin{array}{l}\text { Krisna Iswarayana } \\
08123832059\end{array}$ \\
$\begin{array}{l}\text { Pandu Atmaja } \\
081335622778\end{array}$ \\
\hline $\begin{array}{l}\text { Wira Darma } \\
08256166161\end{array}$ \\
\hline
\end{tabular}

Gambar 12 Tampilan Menu Untuk Melihat Posisi Anak

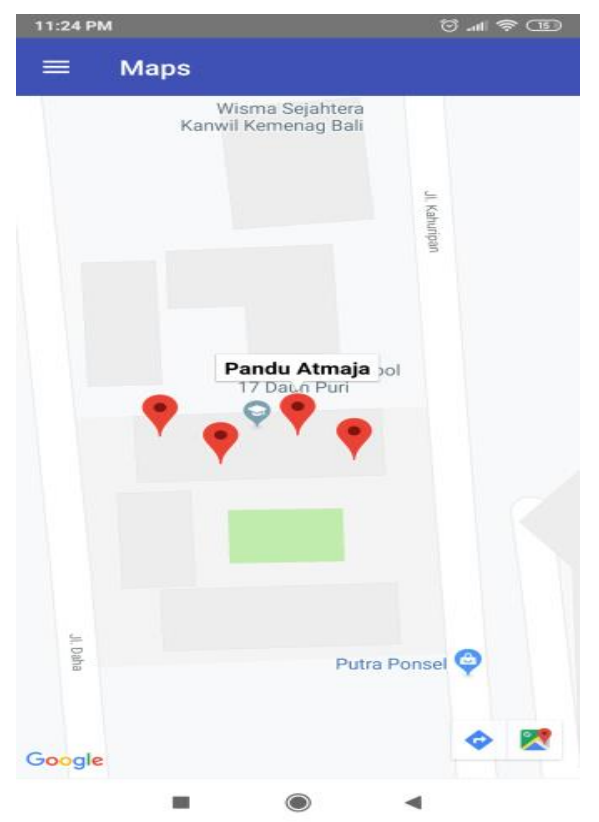

Gambar 14 Tampilan Posisi Semua Anak pada Maps (diperbesar) 


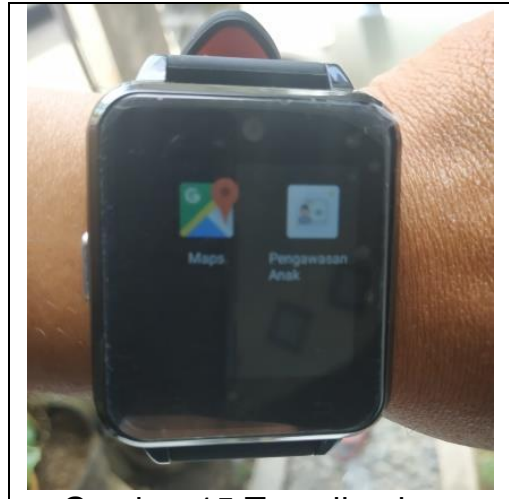

Gambar 15 Tampilan icon aplikasi pada smartwatch

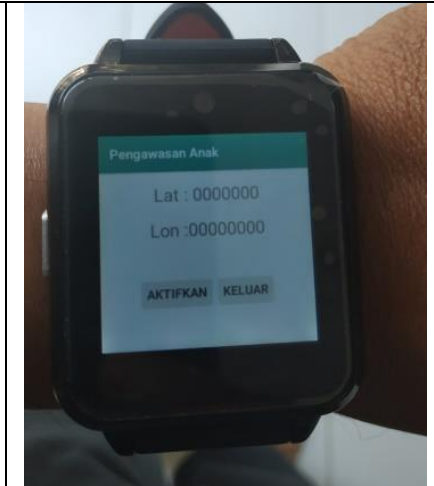

Gambar 16 Tampilan aplikasi sebelum aktif pada smartwatch

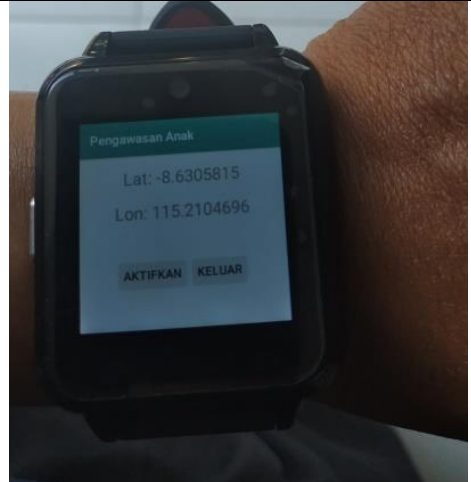

Gambar 17 Tampilan aplikasi setelah aktif pada smartwatch

\section{Kesimpulan}

Aplikasi pemantauan posisi anak-anak dengan gps smartwatch meliatkan beberapa aktor didalamnya. Aplikasi ini membutuhkan aktor "anak" dan aktor "orang tua". Aktor anak akan menggunakan perangkat lunak smartwatch yang dilengapi dengan GPS. Point penting dalam aplikasi ini adalah si anak melalui smartwatch- nya mengirimkan posisi latitude dan longitude dirinya ke server database firebase. Aktor "orang tua" dapat melihat posisi si anak dengan melakukan permintaan data posisi anak ke server firebase. Server akan memberikan data ke smart phone orang tua dengan visualisasi melalui google map. Struktur firebase untuk aplikasi pemantauan anak ini memiliki root data utama yaitu keluarga. Keluarga memiliki sub node didalamnya yaitu node "anak". Node "anak" akan berisa data - data anak dalam satu keluarga. Struktur firebase ini disusun sedemikian rupa disesuaikan dengan informasi yang akan ditampilkan dilayar smart phone orang tua.

\section{Daftar Pustaka}

[1] Viva.co.id (24 Maret 2017). "Kasus Penculikan Anak Tiap Tahun Meningkat", https://www.viva.co.id/berita/nasional/897701-kasus-penculikan-anak-setiaptahunmeningkat. Unduh tgl 24 agustus 2018

[2] Jawad, S.K, Yousef, A.M., Balkiest, E.A, "A Multipurpose Child Tracking System Design and Implementation", International Journal of Soft Computing Appliations, ISSN: 14532277 Issue 4, pp.57-68, 2009.

[3] Kinage, K., Kumari, J., Zalke,P., Kulkarni, M.,"Mobile Tracking Application”, International Journal of Innovative Research in Science, Enggineering and Technology, ISSN: 23198753, Vol. 2, Issue 3, 2013

[4] Muawal, A., Zaman, B., "Implementasi Teknologi GPS Tracking Smartphone Sebagai Aplikasi Monitoring Lokasi Anak". JTRISTE, ISSN: 2355-3677, Vol. 4,No 1, pp.82-86, 2017.

[5] Janika Raun, Rein Ahas, "Defining usual environment with mobile tracking data", Proceding on 14th Global Forum on Tourism Statistics, 23-25 November 2016, Venice, Italy, 2016.

[6] Beeco, J. A., Hallo, J. C., \& Brownlee, M. T. J., "GPS Visitor Tracking and Recreation Suitability Mapping: Tools for Understanding and Managing Visitor Use", Landscape and Urban Planning, 127, 136-145, 2014.

[7] Purnama, B. E., "Pemanfaatan Global Positioning System Untuk Pelacakan Objek Bergerak" . Journal Speed-Sentra Penelitian Engineering dan Edukasi, Vol.2 No 2, 2009.

[8] Segara, R., Subari, "Sistem Pemantauan Lokasi Anak Menggunakan Metode Geofence Pada Platform Android", Jurnal Teknologi \& Manajemen Informatika, Vol. 3, No.1, 2017.

[9] Anusha, R., Naidu R. C. A., "GPS and RFID Based School Children Tracking System", International Journal of Advanced Research in Computer Engineering \& Technology (JARCET), ISSN:2278-1323, Vol. 5, Issue 6, 2016. 
[10] Spek, S. V. D., Schaick, J. V., Bois, P.D., Haan, R.D.,"Sensing Human Activity: GPS Tracking". Sensor, ISSN:1424-8220, Vol. 9, 3033-3055, doi:10.3390/s90403033, 2009.

[11] Chaudhari, T. R., Pathil, A. J., Karhe, R.R., "RFID and GPS Based Child Tracking System With Voice Recognition for Security", International Journalof Scientific Development and Research(IJSDR), ISSN:2455-2631, Vol. 1, Issue 12, 2016.

[12] Khedkar, S., Thube, S, "Realtime Databases for Applications. International Research Journal of Engineering and Technology. Volume 4(6), 2017

[13] Haena Khan (2014). NoSQL: A Database for Cloud Computing" , International Journal of Computer Science and Network. Volume 3(6).

[14] Srivastava, N., Shree, U., Chauhan, N.R, Tiwari D.K. "Firebase Cloud Messaging (Andoid)", International Journal of Innovative Research in Science, Engineering and Technology. Volume 6(9), 2017.

[15] Indrayana I N E, Sudiartha I K G, Suasnawa I W, "Migrasi Model Data Relational Ke Model Data Realtime Database Firebase Untuk Aplikasi Monitoring Wisatawan", Jurnal Sains Terapan Teknologi Informasi (JUST TI), Vol 11 No 1, p12-15,ISSN 2085-6458, 2019.

[16] Sudiartha I K G, Indrayana I N E, Suasnawa I W, Ciptayani P I, "Design and Implementation of Group Tourist Monitoring Application With Realtime Database Firebase", Proceedings of International Conference on Science and Technology (2018), Atlantis Press, 2018.

[17] Google Developers , "Dokumentasi Firebase", https:// firebase.google.com/ docs/database/android/structure-data, unduh Februari 2019.

[18] Sudiartha I K G, Indrayana I N E , Suasnawa I W, "Membangun Struktur Realtime Database Firebase Untuk Aplikasi Monitoring Pergerakan Group Wisatawan", Jurnal IImu Komputer, p96-102, ISSN 2622-321X, 2018.

[19] Almootassem,O., Husain S.H, Parthipan, D., Mahmoud, Q.H., "A Cloud-based Service for Real-Time Performance Evaluation of NoSQL Databases", Cornell University Library, 2017.

[20] Bennett, S., McRobb, S., Farmer, R.,. "Object Oriented Systems Analysis and Design Using UML", Mc Grow Hill, Pennsylvania, United State, 2010.

[21] Osis J., Donins U., "Topological UML Modeling”, ELSEVIER, Pg. 53-82, 2017. 